\title{
WYBRANE LITURGICZNE I LUDOWE TRADYCJE ARABSKIEGO PRAWOSŁAWIA DZISIAJ
}

Streszczenie. Arabowie przyjmowali chrześcijaństwo już od pierwszych wieków jego istnienia. Obecnie wraz z zarabizowanymi Aramejczykami dominują wśród wiernych prawosławnych patriarchatów Antiochii i Jerozolimy, a w minimalnym stopniu należą także do greckiego Patriarchatu Aleksandrii. Prawosławni Arabowie zamieszkują przede wszystkim Syrię, Liban, Palestynę i Jordanię. Mimo niesprzyjających okoliczności trwają w wierze i zachowują własne tradycje. Są one mieszanką różnych wpływów, jednak wyróżniają się na tyle, że można mówić o „arabskim prawosławiu”. Kultywowanie tej lokalnej specyfiki jest możliwe dzięki zasadzie autokefaliczności - czyli niezależności - poszczególnych prawosławnych Kościołów lokalnych. Co więcej, emigrując w różne części świata, zwłaszcza do obydwu Ameryk, prawosławni Arabowie przenoszą swoje zwyczaje liturgiczne i pewne wyrażenia na grunt innych kultur, ewangelizując przy tym inne narody.

Słowa kluczowe: liturgika; chrześcijaństwo arabskie; prawosławie; tradycje lokalne.

Abstract. Selected Liturgical and Folkloric Traditions of Arab Orthodoxy Today. Arabs were embracing Christianity from the first centuries of its existence. Currently together with arabised Arameans they dominate among the faithful of the Orthodox patriarchates of Antioch and Jerusalem; they also belong - to a minimal extent - to 
the Greek Orthodox Patriarchate of Alexandria. Orthodox Arabs live above all in Syria, Lebanon, Palestine and Jordan. Despite unfavourable circumstances, they persist in the faith and keep their traditions. They are a mixture of various influences, however they are enough distinctive to use the term of "Arab Orthodoxy". Due to the rule of autocephaly - that is to say, independence - of the Orthodox local Churches, maintenance of these specifics is possible. Moreover, Orthodox Arabs, because of emigration to other parts of the world, especially to North and South America, in which believers from these patriarchates have founded their own parishes, and in this way evangelise other nations and transmit their traditions to them.

Key words: liturgics; Arabic Christianity; Orthodoxy; local traditions.

Celem tekstu jest refleksja nad tym, czy można mówić o „arabskim prawosławiu” na podstawie wybranych praktyk liturgicznych i paraliturgicznych wśród prawosławnych Arabów. To także opis kultury arabskiej w mniej znanym kontekście - chrześcijańskim, a ściślej: prawosławnym. Takich publikacji po polsku jest niewiele, a konflikty i rewolucje, które przeżywa Bliski Wschód powodują, że coraz więcej prawosławnych Arabów opuszcza swoje rodzime ziemie, co grozi stopniowym zanikaniem ich tradycji. Źródła są różnorodne: prawosławne księgi liturgiczne w języku arabskim, kazania, newsy, nagrania video, zdjęcia, a także uczestnictwo autorki w nabożeństwach prawosławnych arabskiej społeczności i innych tradycji. Artykuł został podzielony na kilka części: rys historyczny; procesje; postawy liturgiczne; w okoliczności śmierci; opisy poszczególnych świąt; podsumowanie.

\section{RYS HISTORYCZNY}

Arabowie przyjmowali chrześcijaństwo już od pierwszych wieków jego istnienia. W opisie Zstąpienia Ducha Świętego, będącym według tradycji prawosławnej jednocześnie narodzinami Cerkwi, czytamy: „[...] i [my] Arabowie - słyszymy ich głoszących w naszych językach wielkie dzieła Boże"1. Prawosławni Arabowie po dziś dzień szczycą się tym zdaniem, co widać choćby w trakcie melorecytacji tego Apostoła (perykopa

${ }^{1} \mathrm{Dz} 2,11$. 
z Dziejów Apostolskich, listów św. Pawła lub listów powszechnych na Boskiej Liturgii) w święto Pięćdziesiątnicy, gdzie wyraz „Al- A Arab” („Arabowie") jest specjalnie przedłużony ${ }^{2}$. Aczkolwiek należy tu zaznaczyć, że chrystianizacja plemion arabskich trwała na przestrzeni kilku wieków, a samo chrześcijaństwo nigdy nie stało się religią większościową wśród Arabów. Mieli jednak oni przedstawicieli swego etnosu i zamieszkałych regionów w postaci biskupów począwszy od pierwszego soboru powszechnego, którzy optowali w głosowaniach za decyzjami później uznawanymi za prawowierne ${ }^{3}$.

Liturgika arabska, zapewne bardzo prosta przez koczowniczy tryb życia, na przełomie IV i V wieku była bliższa tradycji bizantyjskiej ${ }^{4}$. Jednak już sto lat później, przez kontrowersje chalcedońskie, które niejednokrotnie sprowadzały się do konfliktu na tle etnicznym pomiędzy Rzymianami zachodnimi i wschodnimi - tj. Grekami - z ludami tubylczymi, Arabowie zaczęli preferować ryt syriacki ${ }^{5}$. Pojawienie się islamu oraz podbój muzułmańsko-arabski diametralnie zmieniły sytuację zarówno na Półwyspie Arabskim, jak i w prowincji Arabia należącej do Bizancjum. Wielu członków arabskich plemion chrześcijańskich, np. Taġlib, zmuszano do przyjęcia islamu lub zabraniano chrzczenia dzieci - ponieważ od teraz religią jednoczącą wszystkich Arabów miał być islam6 . Jednocześnie Bizancjum przestało być kojarzone z okupantem, co mogło być przyczyną ostatecznego przyjęcia jako własnego przez większość chrześcijańskich Arabów rytu bizantyjskiego, który jednak zarówno wtedy, jak i dzisiaj cechuje się dosyć licznymi odmiennościami lokalnymi. Z kolei wprowadzanie arabskiego jako urzędowego na terenie nowego imperium oraz ujednolicenie jego gramatyki i zapisu pomogło wprowadzić ten język do nabożeństw na masową skalę; druga połowa ósmego stulecia to czas rozpoczęcia inten-

2 Zob. np. Chadi Karam Byzantine chanting on Pentecost, https://www.youtube. com/watch?v=5YdOKJjn2jQ [dostęp: 01.09.18].

3 I. Shahid, Byzantium and the Arabs in the fifth century, Washington D.C. 1989, s. $214-227$.

4 Tenże, Byzantium and the Arabs in the fourth century, Washington D.C. 1984, s. 44.

5 Tenże, Byzantium and the Arabs in the fifth century, s. 227.

${ }^{6}$ K. Kościelniak, Grecy i Arabowie: historia Kościoła melkickiego (katolickiego) na ziemiach zdobytych przez muzutmanów: (634-1516), Kraków 2004, s. 67-78. 
sywnych prac translatorskich na język arabski tekstów liturgicznych rytu bizantyjskiego, których jednym z ważniejszych ośrodków był monaster św. Saby w Palestynie, gdzie już wcześniej część mnichów stanowili Arabowie ${ }^{7}$. Następowała jednocześnie stopniowa arabizacja Aramejczyków. Okres od VI do VIII wieku to również w zasadzie najważniejsza epoka dla bizantyjskiej hymnografii, kiedy kształtowały się również ostatnie znaczące elementy liturgiki bizantyjskiej; wśród czołowych hymnografów, których utwory po dziś dzień, w różnych językach, śpiewane są na prawosławnych nabożeństwach, znaleźli się również semiccy święci, m.in. Roman Melodos, Sofroniusz Jerozolimski oraz Jan Damasceński - ci dwaj ostatni najprawdopodobniej arabskiego pochodzenia ${ }^{8}$. Zatem, Semici, w tym Arabowie, wnieśli istotny wkład w ryt bizantyjski. Jednak przez burzliwe dzieje w życiu liturgicznym prawosławnych Arabów występują też wpływy zachodnie - wprowadzane w czasie krucjat, jak i dużo później, w dobie kolonializmu - oraz greckie, m.in. kiedy w Cerkwi antiocheńskiej przez pewien czas dominowała grecka hierarchia, gdy część tej arabskiej przyjmowała unię z Rzymem, a także przez pojawienie się druku, kiedy drukowano księgi liturgiczne według gotowych greckich wzorców ${ }^{9}$.

Obecnie znaczna część chrześcijańskich Arabów oraz zarabizowanych Aramejczyków wyznaje prawosławie; procent zależy od danego kraju, np. ponad połowa palestyńskich wyznawców Chrystusa to prawosławni ${ }^{10}$. Obydwie te grupy to wierni starożytnych patriarchatów Antiochii i Jerozolimy, a także - w minimalnym stopniu - greckiego Patriarchatu Aleksandrii. Każda z tych Cerkwi jest autokefaliczna, czyli niezależna jedna od drugiej pod względem administracji - włączając $\mathrm{w}$ to tradycje związane $\mathrm{z}$ nią, jak tytulatura czy jednostki kościelne, które

7 The Orthodox Church in the Arab World 700-1700. An Anthology of Sources, red. S. Noble i A. Treiger, 2014, s. 22.

8 Zob. więcej J. Nașrallāh, Manșūr Ibn Sarğūn at-Tağlibī Al-Mảarūf Bi-ălQiddīs Yūḥannā ad-Dimašqū Aw Al-Fatah Al-Islāmī As-Sahl li-ăl-Madīna Dimašq wa Asbābuh, 1950; I. Al-Ḡarwī, Tārīh al-qadiyya al-urtūuduksiyya fī Falastīn, https://almoutran.com/2011/04/1247 [dostęp: 04.07.18].

9 The Orthodox Church in the Arab World, s. 35.

${ }_{10}$ Faith under occupation. The Plight of Indigenous Christians in the Holy Land, red. M. Nseir, M. Quintero, P. Nunu, N. Muaddi, Y. Daher, 2012, s. 11. 
są np. szczególne w Patriarchacie Antiocheńskim ${ }^{11}$; stosowanego języka na nabożeństwach, dokumentach i komunikacji; kultu poszczególnych świętych; szczegółowych regulacji postnych i liturgicznych etc. Wierni ci mieszkają przede wszystkim w Syrii, Libanie, Palestynie i Jordanii oraz na emigracji w różnych zakątkach świata, m.in. Ameryce Łacińskiej i Stanach Zjednoczonych, gdzie członkowie tych patriarchatów już od ponad stu lat, tworząc własne parafie, ewangelizują przy tym inne narody i przekazują im swoje tradycje, wyrażane również w zapożyczeniach językowych funkcjonujących w angielskim i hiszpańskim, jak np. „khouria”

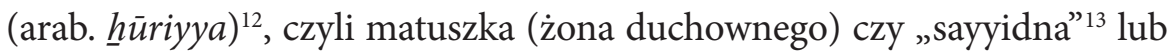
„sayedna” ${ }^{14}$ (arab. sayyidnā), czyli władyka (hierarcha dowolnej rangi). Wspólnoty te tworzone są nie tylko przez osoby arabskiego pochodzenia, lecz również przez Amerykanów i Latynosów.

\section{PROCESJE}

Ryt bizantyjski przewiduje procesje na okazje takie, jak: wyświęcenie cerkwi, święto parafialne, wielkie poświęcenie wody na Objawienie Pańskie, jutrznia Wielkiej Soboty, Noc Paschalna oraz Okres Paschalny, Zaśnięcie Bogurodzicy, w niektórych tradycjach również na Niedzielę Tryumfu Ortodoksji i Sobotę Łazarza lub Niedzielę Palmową. Procesja w rycie bizantyjskim zasadniczo - poza Epifanią - polega na jednokrotnym (Wielka Sobota i Zaśnięcie Bogurodzicy) lub trzykrotnym okrążeniu cerkwi zgodnie z ruchem przeciwnym do wskazówek zegara. Jednak prawosławni Arabowie urządzają procesje nie tylko na wszystkie wymienione wyżej okazje, lecz również inne, np. na świętej Barbary. Niektóre z nich łączą religię i ludowość - nie mają przebiegu typowego dla procesji w rycie bizantyjskim, w którym najbardziej powszechnym typem jest

\footnotetext{
11 Zob. więcej Ğ. Huụ̂, Al-Bațriyark, „Ra 'iyyatī”, 52 (2012).

12 Antiochian Women of the East (AWE), http://ww1.antiochian.org/awe [dostęp: 26.07.18].

13 Zob. np. https://www.stlukeorthodox.net/administration.html [dostęp: 02.08.18].

14 Zob. np. http://www.antiochian-orthodox.co.uk/sayidna/message-sayedna-silouan-october-2017/ [dostęp: 02.08.18].
} 
trzykrotne okrążanie świątyni przy biciu dzwonów lub tzw. biła/semantronu (drewniana belka, w którą uderza się młotkiem) przy ewentualnym śpiewie hymnów danego święta, gdzie za trzecim razem są cztery stacje na czytanie wybranych fragmentów Ewangelii. Procesjom tym towarzyszą również inscenizacje, przebrania i tańce, co zostanie omówione w podrozdziale opisującym poszczególne obyczaje świąteczne. Dlatego po arabsku istnieją dwa słowa określające procesje cerkiewne: dawra (rdzeń związany z okrążaniem, czyli bardziej „klasyczna” procesja) oraz zayyāḥ (rdzeń związany z odkryciem czegoś, wyniesieniem i pokazaniem, np. krzyża, ikon, platform inscenizacyjnych - można to odnieść to procesji bardziej związanych z ludowością), i choć mają inną etymologię, obecnie czasem stosowane są wymiennie.

Osobnymi rodzajami procesji w rycie bizantyjskim są tzw. małe i wielkie wejście w trakcie Boskiej Liturgii z konsekracją (czyli, najczęściej, św. Jana Chryzostoma lub św. Bazylego Wielkiego) - na Liturgii Uprzednio Uświęconych Darów występuje tylko jedna, podobna do wielkiego wejścia. Małe wejście następuje po śpiewie dwóch antyfon, w trakcie trzeciej antyfony, a przed trisagionem i czytaniami z Pisma Świętego. To w trakcie tego wejścia wynoszony jest Ewangeliarz. W tradycji arabskiej, w przeciwieństwie np. do polskiej, ta procesja kleru i asysty liturgicznej nie tylko przechodzi przed ikonostasem, ale nierzadko przez całą cerkiew. Wielkie wejście z kolei następuje po kazaniu, a przed Wyznaniem wiary i Anaforą Eucharystyczną. Wówczas kapłani wychodzą z przygotowanymi do konsekracji Darami przed ikonostas w trakcie śpiewu Hymnu Cherubinów, wypowiadając na głos różne intencje, po czym przenoszą Dary na ołtarz. W tradycji arabskiej, nie tak jak w polskiej, ta procesja przechodzi przez całą świątynię. Oficjalnie małe i wielkie wejście po arabsku to odpo-

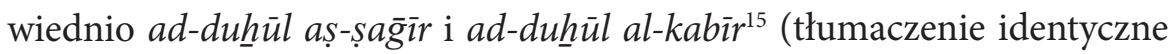
z polskim), jednak w języku potocznym określa się je mianem ad-dawra aṣ-ṣaḡìra i ad-dawra aș-kabìra ${ }^{16}$ - jak widać, występuje tu ponownie słowo dawra, czyli można to tłumaczyć jako „okrążenie małe”/ „procesja mała” oraz „okrążenie duże”/ „procesja duża”.

${ }^{15}$ Al-Quddās al-Ilahī wa-ma 'ānīh, https://almoutran.com/2011/04/1216 [dostęp: 06.08.18].

16 Tamże. 
Jeszcze innym typem procesji są wyjścia kleru i asysty liturgicznej na środek świątyni w trakcie litiji (błogosławieństwo pięciu chlebów, wina i oliwy przy modlitwach za cały świat i litanii do wszystkich świętych na wieczerni w wigilie świąt $\mathrm{z}$ grona 12 wielkich oraz innych ważnych, jak np. patronalne) oraz śpiewie polijeleju (psalmy 134-135) ${ }^{17}$ - a czasem troparionu (krótki hymn ukazujący esencję święta lub świętego) - na jutrzniach niedzielnych i świątecznych. W tym drugim przypadku, w tradycji arabskiej, podobnie jak w innych tradycjach południowych, dopiero wtedy wynosi się na środek ikonę święta lub świętego dnia, która zostaje tam aż do tzw. oddania, czyli zakończenia święta. Jednak o ile w wielu miejscach ikona ta po prostu jest wynoszona, o tyle u Arabów kapłan przechodzi z nią przez całą cerkiew.

\section{POSTAWY LITURGICZNE}

Mimo istnienia pewnego schematu zachowań liturgicznych w rycie bizantyjskim, każda Cerkiew lokalna, nawet parafia, ma własne. Co więcej, różnią się one pomiędzy poszczególnymi wiernymi - są one zależne od osobistych pobożności i ekspresji. Arabowie wykształcili kilka postaw typowych dla nich.

Z wszystkimi wymienionymi wcześniej rodzajami procesji wiąże się szczególny arabski zwyczaj, a jest nim zbieranie baraki, tj. błogosławieństwa. O ile w prawosławiu powszechnie przyjęte jest całowanie ikon po wejściu do świątyni czy też po odczytaniu Ewangelii na jutrzni, krzyża trzymanego przez kapłana na koniec Boskiej Liturgii, relikwii (w tym przykładanie się do nich) oraz rąk kapłana na powitanie lub z prośbą o błogosławieństwo jako do biskupa lub własnego ojca duchowego i/ lub spowiednika, jako wyraz szacunku, przyjaźni i więzi, o tyle jednak u Arabów jest to bardziej rozbudowane. Kiedy przechodzi procesja, wierni czynią znak krzyża, całują prawą dłoń, a następnie dotykają czy to przechodzącego kapłana, czy skraju jego szaty, czy niesionej Ewangelii, ikony, a nawet Darów przygotowanych do Eucharystii w trakcie wielkiego

${ }_{17} \mathrm{~W}$ pracy stosowana jest numeracja przyjęta w tradycji prawosławnej. 
wejścia. Po tym taka osoba zazwyczaj znowu czyni znak krzyża ${ }^{18}$. Jest to wyraz pobożności i czci, ale również właśnie próba otrzymania szczególnego błogosławieństwa, na wzór ewangelicznej kobiety cierpiącej na krwotok $^{19}$.

Inną charakterystyczną postawą liturgiczną dla Arabów jest tzw. „oranta”, czyli rozłożenie rąk na modlitwę Ojcze nasz odmawianą czy to na Boskiej Liturgii czy na innych nabożeństwach. Modlitwa ta jest mówiona - nie śpiewana, jak to np. zazwyczaj się dzieje wśród różnych Słowian - przez cały zgromadzony lud, ewentualnie psalmista może ją melorecytować.

Jak jest mowa o pewnym kodzie zachowań, nie sposób tu pominąć kwestii związanych z ubiorem. Każda Cerkiew lokalna - tj. autokefaliczna lub autonomiczna - a nawet parafia ma różne zwyczaje związane z odzieniem zakładanym do świątyni, przy czym z całą pewnością musi być ono godne i skromne. Arabki rzadko noszą chustki do cerkwi - częściej można je spotkać u Palestynek, jako część tradycyjnego, narodowego ubioru, oraz u Jordanek ${ }^{20}$; może to być związane, podobnie jak w Serbii i Bułgarii, z chęcią wyróżnienia się od muzułmanek. Zazwyczaj Arabki noszą też krzyżyk na wierzchu - widoczny jest on na ubraniu. Nie ma również kwestii spódnic - jak to bywa zwłaszcza u wschodnich Słowian; popularniejsze są spodnie. Jeśli chodzi o mężczyzn, zwłaszcza w mniejszych miejscowościach w Palestynie, Jordanii i Syrii można się spotkać z tym, iż bardziej przywiązani do tradycji, przychodzą do cerkwi w dżelabie (długa, prosta szata) i kufijji, w Polsce znanej bardziej jako „arafatka”. To chusta całkowicie biała albo w biało-czarną lub biało-czerwoną kratę - to zależy od regionu - przewiązana czarnym kółkiem zwanym ’iqāl. Bywa,

${ }_{18}$ Zob. np. Zayyāḥ Aš-Šànī fī kanīsa As-Sayyida bi-Tarțūs 2014, https://www. youtube.com/watch?v=qd9TFfd-Qoo, 06.08.2018; Quddās Hamīs al-Asrār Dawrat alQarābìn, https://www.youtube.com/watch?v=MOU6zwyODfk [dostęp: 06.08.18].

${ }_{19}$ Mk 5, 25-34.

${ }^{20}$ Zob. np. zdjęcia z parafii św. Jerzego w As-Salț w Jordanii, https://

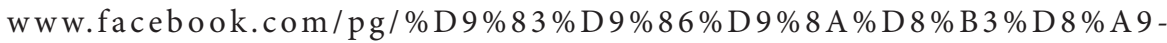
- \%D 8\%A7\%D9\% 84\%D9\% 82\%D8\%AF\%D9\% 8A\%D 8\%B3- \%D8\%AC\%D 8\%A7 \% D $9 \% 88$ \% D 8 \% B 1 \% D 8 \% A C \% D 9 \% 8 A \% D $9 \% 88$ \% D 8 \% B 3 - \% D 8 \% A 7\%D9\%84\%D8\%B3\%D9\%84\%D8\%B7-Saint-George-Church-Salt-387124751342927/ photos/?tab=albums [dostęp: 08.08.18]. 
że zakładana jest sama chusta, bez dżelaby ${ }^{21}$. Wcześniej owa chusta była czymś bardziej powszechnym ${ }^{22}$, obecnie jest dużo rzadszym zjawiskiem. W związku z tą chustą, a konkretnie 'iqālem, wiąże się pewien protokół - jest on zdejmowany na ważne momenty, jak np. błogosławieństwo biskupa, modlitwa Ojcze nasz czy moment przystąpienia do Kielicha Eucharystycznego ${ }^{23}$.

Sam biskup przewodzi lokalnej społeczności wiernych, a kwestie liturgiczne związane z nim są bliższe tradycji greckiej, co widać m.in. w umiejscowieniu jego tronu - nie jest on w części ołtarzowej, lecz przed ikonostasem, w południowej części świątyni. Jednak, w odróżnieniu od Greków, bywa on dosłownie przy ikonostasie, a nie w pewnym oddaleniu $^{24}$. Nazywane 'arš al-usquf („tron biskupa”) lub, bardziej potocznie, kursī al-usquf („krzesło biskupa”) ${ }^{25}$. Jest to podwyższenie z oparciem, na którym zazwyczaj znajduje się ikona Chrystusa Arcykapłana lub Pantokratora. Jednym z elementów intronizacji biskupa obejmującego katedrę - czy to jako ordynariusz diecezji, czy biskup pomocniczy ( $w$ tradycji prawosławnej katedra nawet $\mathrm{w}$ takim przypadku nie może być tytularna, lecz jest to cerkiew na obszarze diecezji, gdzie hierarcha ma być wikariuszem), czy patriarcha - jest zaprowadzenie i posadzenie go w tym właśnie miejscu ${ }^{26}$. To $\mathrm{z}$ tego miejsca hierarcha przewodniczy nabożeństwom innym niż Liturgia - zwłaszcza wieczerni i jutrzni, stąd też zaczyna śpiew ważnych hymnów, np. wykonując pierwsze zdanie lub cały irmos (pierwsza zwrotka, nawiązuje do konkretnego kantyku biblijnego i jednocześnie danego święta) pierwszej pieśni danego kanonu świątecznego ${ }^{27}$. Specyficzne dla arabskiego prawosławia kwestie związane

${ }^{21}$ Zob. np. Al-Fuhayṣ.. tārīh hạafil wa-mutağaddir, https://www.ammonnews.net/ article/140275, [dostęp: 08.08.18].

${ }^{22}$ Zob. np. Mazmūr Al-Mīlād.. ğawqat kanīsat Mār Ilyās, https://www.facebook. com/kfarbou.site/videos/1121124667911630/ [dostęp: 08.08.18].

${ }^{23}$ Zob. tamże.

${ }^{24}$ Tuqūs al-Kanīsa al-Urtūuduksiyya, http://www.beitsahourchurch.ps/faithandspirituals/ourfaith/ritual [dostęp: 09.08.18].

25 Tamże.

${ }^{26}$ Kitāb al-Afh̆ūiūgī al-Kabìr, Beirut 1955, s. 259.

27 Zob. np. Quddās 'ìd Al-Mìlād al-Mağìd min al-katidrā'iyya al-Maryamiyya li-r-rūm al-urtuduks bi-Dimašq, https://www.youtube.com/watch?v=HhWkqBaOHqk [dostęp: 12.07.18]. 
z hierarchą są dwie. Pierwsza $\mathrm{z}$ nich to - nie zawsze występujące - niesienie nowego ordynariusza do swojej katedry na ramionach w ramach uroczystości ingresowych lub pierwszej wizyty arcypasterskiej w danym miejscu $^{28}$. Druga to malutki ewangeliarz trzymany w prawym ręku przez hierarchę $\mathrm{w}$ trakcie nabożeństw innych niż Liturgia oraz podczas procesji, którym też np. błogosławi ${ }^{29}$.

\section{W OKOLICZNOŚCI ŚMIERCI}

Podobnie jak w innych kulturach, po czyjejś śmierci przygotowywany jest nekrolog; obecnie bywają one publikowane także na w Internecie - na stronie internetowej lub facebookowej parafii albo też miejscowości; Latakia ma np. specjalną stronę na Faacebooku zadedykowaną tylko prawosławnym nekrologom: Wafayāt mațrāniyya Al-Lādākiyya li-r-rūm al-urt $\underline{u} \underline{d} u k s^{30}$ („Zgony prawosławnej bizantyjskiej metropolii Latakii”). Na takim nekrologu znajduje się zazwyczaj kilka elementów, m.in. krzyż, zdjęcie zmarłego (w przypadku mężczyzny może być ono w kufiji) i jego pełne imię (tzn. sięgające czwartego lub piątego pokolenia wstecz; może też pojawić się nazwa rodu), cytat z Pisma Świętego (np. J 11, 25-26), bliskie osoby pogrążone w żałobie, datę śmierci (którą poprzedza poetycka formuła, np. intaqala ilà al-amğād as-samawiyya - „przeniósł się do chwał niebiańskich”), wiek, data i miejsce pogrzebu ${ }^{31}$. Zazwyczaj pojawia się też informacja o miejscu i godzinie nabożeństwa na trzeci, dziewiąty i czterdziesty dzień od śmierci ${ }^{32}$ - zgodne z prawosławną tradycją, są to dni, kiedy szczególnie powinno się modlitewnie pamiętać o zmarłym, gdyż na trzeci dzień zmartwychwstał Chrystus, dziewięć to liczba rang

${ }_{28}$ Zob. np. Ad d-dikrà 30 li-ziyārat mațrān Hamā İliyya Salībā ilà As-Suqaylabiyya, https://www.youtube.com/watch?v=AntGTCJ28UA [dostęp: 13.07.18].

${ }_{29}$ Zob. np. Itnayn al-Bā' 'ü $\underline{t}$ fì dayr Mār Ilyās ar-Rīh, https://www.facebook. com/pg/tartous.orthodox/photos/?tab=album\&album_id=1722114207848790 [dostęp: 21.07.18].

${ }^{30}$ https://www.facebook.com/pg/Lattakiaorthodoxdeath/about/?ref=page_internal [dostęp: 02.09.18].

31 Zob. np. https://www.facebook.com/fuheis/photos/a.661283083882301/ 2115367438473851/ [dostęp: 30.08.18].

32 Tamże. 
Mocy Bezcielesnych, a na czterdziesty dzień odbywa się sąd nad duszą, gdzie ma przebywać aż do paruzji - wcześniej duch zmarłego błąka się po miejscach mu bliskich na Ziemi. W przypadku Jordanii podaje się również o miejscu i godzinach przyjmowania kondolencji przez bliskich zmarłego $^{33}$; czasem te miejsca są różne dla kobiet i mężczyzn ${ }^{34}$.

Zasadniczo występują trzy formuły grzecznościowo-modlitewne w ramach reakcji na informację o czyjejś śmierci. Pierwsza to li-yakun dikruh mu'abbadan ${ }^{35}$ („niech będzie pamięć jego wieczną). Jeśli zmarła kobieta, do słowa dikr („pamięć”) dodawany jest zaimek „hā” , czyli „jej”, zaś jeśli chodzi o grupę osób lub wszystkich zmarłych, do tego wyrazu doczepia się zaimek „hum” („ich”). Takie sformułowanie występuje powszechnie w różnych prawosławnych tradycjach, w cerkiewnosłowiańskim brzmi ono jak wiecznaja pamiat („wieczna pamięć”). Druga formuła to Al-Masīh qām! " „Chrystus zmartwychwstał!”), które jest również pozdrowieniem w Okresie Paschalnym - obydwie jej funkcje również są zachowane w całym prawosławnym świecie. Trzecia formuła to Allāh yarhamuh $^{37}$ („Niech Bóg zmiłuje się nad nim”) - wobec mężczyzny i Allāh yarhamuhā („Niech Bóg zmiłuje się nad nią”) - wobec kobiety. Jest ona typowa tylko dla użytkowników języka arabskiego, w tym wyznających islam. Warto tu także odnotować, że mówiąc o zmarłym hierarsze, stosuje się wyrażenie al-mutallat ar-raḥmāt ${ }^{38}$ („trzykrotnego zmiłowania”) - jest ono charakterystyczne tylko dla tradycji arabskiej; być może odnosi się ono do tego, iż biskup przeszedł przez trzy stopnie święceń.

Specyficzną tradycją już na samym pogrzebie jest ar-raqșa al-ahīira - „ostatni taniec”. Wydaje się częściej praktykowany w Libanie, być może obecny jest również w tradycjach innych chrześcijańskich wyznań arabskojęzycznych. Polega on na podrzucaniu trumny przez bliskich zmarłego

33 Tamże.

34 Zob. np. https://www.facebook.com/fuheis/photos/a.661283083882301/ 1146068218737116/ [dostęp: 30.08.18].

35 Zob. np. Kitāb al-Afhhūlūgì aṣ-Sạ̄ìr, Ṭarāblus 1989, s. 244.

36 Zob. np. https://www.facebook.com/Lattakiaorthodoxdeath/photos/a. 597079183765673/1172065269600392 [dostęp: 02.09.18].

37 Tamże.

38 Zob. np. Al-Mutallaț Ar-Raḥmāt al-mațān Ḡrīgūuriyūs Ğabāra, https://www. orthodoxlegacy.org/?p=196 [dostęp: 06.09.18]. 
płci męskiej w drodze do cerkwi lub przed nią. Może temu towarzyszyć bicie dzwonów lub gra instrumentów, np. bębnów ${ }^{39}$.

\section{OBYCZAJE ŚWIĄTECZNE - WIELKI TYDZIEŃ}

Centralnym punktem roku liturgicznego w tradycji bizantyjskiej jest Wielki Tydzień. Jego preludium są Sobota Wskrzeszenia Łazarza i Niedziela Palmowa, a zwieńczeniem Pascha - Niedziela Zmartwychwstania. Nabożeństwa tych dni należą do najstarszych i najbardziej rozbudowanych, jednak w różnych Cerkwiach lokalnych, a nawet regionach, mają swój własny koloryt poprzez miejscowe zwyczaje.

Sobota Wskrzeszenia Łazarza to dzień po zakończeniu czterdziestodniowego Wielkiego Postu, radosne święto, czego wyraz widać w lżejszym poście, uroczystych nabożeństwach, jak i obyczajach różnych prawosławnych wspólnot. U Arabów charakterystyczną dla tego i następnego dnia jest paraliturgiczna pieśń Ifraḥi yā Bayt 'Aniyā (Raduj się Betanio), napisana w XIX wieku przez prawosławnego metropolitę Himșu Atanazego ('Ațā Ăllāha) w arabskiej odmianie szóstego tonu bizantyjskiego, nazywaną maqamem (wzór melodyczny) hị̆ḡa kār. Jest ona śpiewana - zamiast koinonikionu (hymn na Komunię) tego świę$\mathrm{ta}^{40}$. Jest to niezwykła sytuacja, gdyż właściwie tak koinonikionów, jak i innych hymnów, w różnych tradycjach raczej się nie zastępuje. Pieśń ta wykonywana jest również na procesji po Boskiej Liturgii dzień później w Niedzielę Palmową. Została ona również przetłumaczona na angielski i hiszpański, i w tych językach - czasem na przemian z arabskim - jest śpiewana w parafiach antiocheńskich obydwu Ameryk ${ }^{41}$. Wśród mieszkańców palestyńskiej miejscowości Bayt Ğālā, zamieszkałej w dużej mierze przez prawosławnych, jeszcze do końca XX wieku istniał zwyczaj, obecny również w Bułgarii, Grecji i na Cyprze chodzenia dzieci po domach, któ-

39 Zob. np. Lubnān yuwaddi 'šahīdan ğarìmat Istanbūl al-irhābiyya Ilyās Wardīnī wa-haykal muslim wasat hidād wațan̄, https://www.youtube.com/watch?v=-BSRUnQBS4A [dostęp: 06.09.18].

${ }^{40}$ Rejoice, O Bethany, http://ww1.antiochian.org/sites/default/files/rejoice_o_ bethany.pdf [dostęp: 06.09.18].

41 Tamże. 
re w zamian za przekazanie wieści o tym, że Łazarz został wskrzeszony, dostawały jajka i cukierki, które już tydzień później, po 48 dniach postu, na Paschę, mogły być spożyte ${ }^{42}$.

Niedziela Palmowa, czyli święto tryumfalnego wjazdu Chrystusa do Jerozolimy, zwana jest potocznie Ahad aš-Ša 'ānīn („Niedziela Hosanny”). Również ona ma radosny i uroczysty charakter, bez elementów pasyjnych, podobnie jak we wszystkich rytach wschodnich, dopiero wieczorem, zgodnie z Ewangelią (por. Mt 21, 12-17), nastrój nabożeństw powoli się zmienia. Obok wspomnianej procesji przy śpiewie pieśni Ifraḥ̄ yā Bayt 'Aniya a tradycji arabskiej, a ściślej - libańskiej i syryjskiej - jest to, iż dzieci przychodzą do cerkwi bardzo uroczyście ubrane (lub wręcz przebrane za jakieś postaci np. z bajek) ze zdobioną świecą w ręku ${ }^{43}$. Trzymają one również, podobnie jak dorośli, palemki - w zależności od regionu różnią się one dosyć znacznie wyglądem. Bywają też przypinane do ubrania, i bardziej pobożni ludzie noszą je przez cały Wielki Tydzień, aby nie zapomnieć, tak jak Żydzi, że Jezus jest oczekiwanym Mesjaszem. Z kolei rola dzieci tego dnia nawiązuje do tego, że na powitanie Chrystusa w Jerozolimie wybiegło wielu młodych mieszkańców miasta i pielgrzymów ${ }^{44}$, co jest też widoczne w ikonografii tego święta. Zresztą ikona Niedzieli Palmowej jest nie tylko niesiona $\mathrm{w}$ procesjach, lecz także może być elementem instalacji - np. na łodzi czy drewnianej wieży - stawianych tego dnia przed cerkwiami w tradycji arabskiej ${ }^{45}$.

$\mathrm{Na}$ tzw. Jutrzni Oblubieńca zwanej po arabsku Salāt Al-Hatan ${ }^{46}$ (dosłownie „Modlitwa Oblubieńca”) sprawowanej w nocy z Niedzieli Palmowej na Wielki Poniedziałek, z Wielkiego Poniedziałku na Wielki Wtorek oraz z Wielkiego Wtorku na Wielką Środę zasadniczo można sie spotkać tylko z jednym elementem typowo arabskim, nieobecnym w innych tradycjach rytu bizantyjskiego. Jest to różne zakończenie troparionu tych trzech pierwszych dni Wielkiego Tygodnia; w pozostałych tradycjach

${ }^{42}$ Zob. więcej D. Koski, Roum Orthodox Traditions of Beit Jala, Palestine, s. 10.

${ }^{43}$ Ğ. Hudụr, Ahad aš-Ša 'ānīn, „Ra iyyatì”, 15 (2009).

44 Tamże.

${ }^{45}$ Zob. np. Aš-Ša ānīn fì ad-dār al-batriyarkiyya fì Dimašq min al-kanīsa Al-Maryamiyya, https://www.facebook.com/pg/Antiochpatriarchate.org/photos/?tab=album\&al bum_id=914698888633825, [dostęp: 06.09.18].

46 At-Ta ziya al-Haqīqiyya fì ăṣ-Salawāt al-Ilahiyya, New York 1940, s. 593. 
brzmi ono zawsze - zarówno za każdym z trzech razy, kiedy jest śpiewany na jutrzni, jak i każdego z trzech dni - „dla Bogurodzicy zmiłuj się nad nami”. Jednak w arabskich wydaniach liturgicznych można się spotkać z zaleceniem, że dopiero za trzecim razem (czyli po „I teraz i zawsze...”) śpiewu tego troparionu każdego dnia następuje to zawołanie, jednak za pierwszym (czyli po trzykrotnym „Alleluja”) i drugim razem (czyli po „Chwała Ojcu...”) jest ono inne, a mianowicie: w Wielki Poniedziałek - „Za wstawiennictwem Bezcielesnych zmiłuj się nad nami”; w Wielki Wtorek - „Za wstawiennictwem Poprzednika [tj. Jana Chrzciciela] zmiłuj się nad nami”; w Wielką Środę - „mocą Krzyża Twego zmiłuj się nad nami" ${ }^{\prime 4}$. Wynika to z cyklu tygodniowego w rycie bizantyjskim. Z jednej strony, można tę praktykę uznać za sprzeczną z Tradycją, gdyż czas od Soboty Łazarza do Niedzieli Przewodniej (tydzień po Passze) nie podlega żadnym cyklom stałym, nie są wspominani żadni święci poza momentem rozesłania, nie ma nabożeństw w konkretnych intencjach (w tym za zmarłych) itd. Z drugiej jednak strony, to z Wielkiego Tygodnia w dużej mierze pochodzi cykl tygodniowy. To zalecenie jednak nie występuje we wszystkich wydaniach ${ }^{48}$.

Wielki Czwartek potocznie określany jest mianem Hamīs al-Asrāra ${ }^{49}$, czyli „Czwartek Tajemnic”. Określenie „Tajemnice” nawiązuje do Sakramentów - bo tak są określane one w prawosławiu - a zwłaszcza Eucharystii, która tego dnia została ustanowiona, a Dary Eucharystyczne bywają nazywane w całym prawosławnym świecie „Świętymi Tajemnicami”. To słowo również odwołuje się do Mistycznej/Tajemnej Wieczerzy (arab. Al- 'Ašâ'i as-Sirrī) - Prawosławie rzadko nazywa ją „Ostatnią” - którą uobecnia Boska Liturgia Wielkiego Czwartku. Właściwie chyba jedynym charakterystycznym tylko dla Arabów tego dnia może być - a i tak się wydaje, że rzadkie - sprawowanie Boskiej Liturgii na ołtarzu nie za ikonostasem, ale przed nim ${ }^{50}$.

W późny wieczór Wielkiego Czwartku sprawowana jest Jutrznia

47 Tamże, s. 594.

48 Zob. np. Triyūdūn, Ṭarābulus 1996, s. 347.

${ }^{49}$ Hamīs al-Asrār al-Muqaddas- Usbū' al-'Ālām - gasl al-arğul, http://greekorthodox-beitsahour.blogspot.com/2014/04/blog-post_17.html [dostęp: 10.09.18].

${ }^{50}$ Zob. np. Quddās Hamīs al-Asrār dawrat Al-Qarābīn, https://www.youtube. com/watch?v=MOU6zwyODfk, [dostęp: 10.09.18]. 
Wielkiego Piątku, która jednak bardziej przypisana jest jutrzni i zachowuje jej ramy, jednak w zasadzie jest to wyjątkowe nabożeństwo, podobnie jak niemalże wszystkie zaczynające się od Jutrzni Wielkiego Czwartku, która rozpoczyna Triduum Paschalne, po arabsku Talātiyyat ‘ìd al-Fiș̣h ${ }^{51}$ („Potrójność święta Paschy”). W każdej tradycji to nabożeństwo czuwania z Wielkiego Czwartku na Wielki Piątku ma inną nazwę, w arabskiej jest to Hidmat Anāğ̃̄l al-'Ālām ${ }^{52}$ - „Służba/Nabożeństwo Ewangelii Cierpień”. Jest to nawiązanie do tego, że najważniejszy element tego nabożeństwa stanowi 12 perykop ewangelicznych przeplatanych śpiewem hymnów. Jego centralnym elementem powinno być wyniesienie dużego Krzyża przy śpiewie XV antyfony Wielkiego Piątku - obrzęd ten zachowują zasadniczo wszystkie tradycje, włącznie z arabskiej, a z pominięciem Polski i niektórych miejsc na wschodniej słowiańszczyźnie. Drugim elementem charakterystycznym dla Arabów i niektórych innych tradycji południowych, a nieobecnym w Polsce, jest zapalanie kolejnej z dwunastu świec przy rozpoczęciu czytania kolejnej Ewangelii. U Arabów podświeczniki na nie umieszczane są przed ikonostasem i bogato zdobione ${ }^{53}$.

W sam Wielki Piątek, wczesnym popołudniem, po sprawowanych rano Królewskich Godzinach Kanonicznych, celebrowana jest wieczernia, która jednak ma tylko jej strukturę, więc nazywana jest różnie, u Arabów funkcjonuje jako Hidmat Inzāl Al-Mașlū $b^{54}$, czyli „Służba/Nabożeństwo Zdjęcia Ukrzyżowanego". Nazwa wywodzi się z obrzędu nieznanego większości Słowian; polega on na rzeczywistym zdjęciu wizerunku Chrystusa z krzyża wyniesionego minionej nocy w trakcie czytania Ewangelii tego nabożeństwa. Tę ikonę Ukrzyżowanego - kapłani lub świeccy (mogą to

51 Talätiyyat 'ìd al-Fiṣh, https://antiochpatriarchate.org/ar/page/\%D8\%AB\%D9\%84\%D8\%A7\%D8\%AB\%D9\%8A-\%D8\%A9-\%D8\%B9\%D9\%8A\%D8\%AF-\%D8\% A7\%D9\%84\%D9\%81\%D8\%B5\%D8\%AD/1413/ [dostęp: 11.09.18].

52 Tamże.

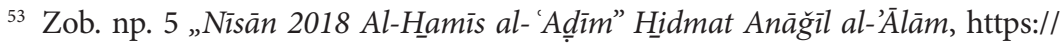
www.facebook.com/pg/HOLY.CROSS.CHURCH.SY/photos/?tab=album\&album _ $\mathrm{id}=1876555369086139$ [dostęp: 11.09.18].

${ }^{54}$ Zob. np. harmonogram prawosławnych nabożeństw wielkotygodniowych w Zahli, https://www.facebook.com/GreekOrthodoxArchdiocesesOfZahle/photos/a$.478407512260814 .1073741829 .352813064820260 / 1316678991766991 /$ ?type $=3 \&$ theater [dostęp: 11.09.18]. 
być też kobiety - zawijają w białe płótno, czemu może towarzyszyć rzucanie kwiatów i kropienie wodą święconą ${ }^{55}$. Krzyż zostaje pusty, i służy jako nagrobny - na koniec tego nabożeństwa we wszystkich tradycjach rytu bizantyjskiego wynosi się zza ikonostasu tzw. płaszczanicę (płótno z wizerunkiem Chrystusa w grobie lub składanego do niego, po arabsku znane pod grecką nazwą al-ibìtāfiyūn $\left.{ }^{56}\right)$ i kładzie ją na środku świątyni, na swego rodzaju katafalku (arab. an-na $\mathfrak{s}^{57}$ ) otoczonym kwiatami, na którym zostaje położony również ewangeliarz.

Ten grób to centralne miejsce nabożeństwa Jutrzni Wielkiej Soboty, która, oczywiście, nie jest typową jutrznią, i ma charakter czuwający - powinna być sprawowana nad ranem, jednak nierzadko, z różnych względów, celebruje się ją w późny wielkopiątkowy wieczór. Znowuż, w różnych tradycjach ma ona różne nazwy, w arabskiej to Hidmat Ğannāz Al-Masīh ${ }^{58}$, czyli „Służba/Nabożeństwo Pogrzebu Chrystusa”. Znaczą część tego nabożeństwa stanowi wspólny śpiew wszystkich zgromadzonych Pieśni Pochwalnych (arab. At-Taqārī $\underline{d}^{59}$ ), tzn. troparionów przyporządkowanych do wersetów najdłuższego psalmu, czyli 118, podzielonych na trzy tzw. stacje - każda ma inną melodię. Nabożeństwo to w wersji arabskiej ma przebieg zbieżny z innymi tradycjami - na jego koniec, przy śpiewie trisagionu, obnosi się płaszczanicę wokół cerkwi lub osiedla. Właściwie na całym świecie część pobożnych prawosławnych starają się pod nią przejść - u Arabów - być może w celu uniknięcia chaosu - po procesji duchowni trzymają płaszczanicę wysoko nad wejściem do cerkwi lub blisko ikonostasu, tak że wierni przechodzą pod nią bez przepychanek ${ }^{60}$.

${ }^{55}$ Zob. np. Tanzīl Al-Maṣlūb, https://www.youtube.com/watch?v=ws8GHvSr0-I [dostęp: 11.09.18].

56 Talātiyyat 'ìd al-Fiṣh .

57 Tamże.

58 Zob. np. harmonogram prawosławnych nabożeństw wielkotygodniowych w Zahli, https://www.facebook.com/GreekOrthodoxArchdiocesesOfZahle/photos/a$.478407512260814 .1073741829 .352813064820260 / 1316678991766991 /$ ?type=3\&theater [dostęp: 11.09.18].

59 Triyüdūn, s. 397.

60 Zob. np. Hidmat ğannāz Rabbinā wa-Muhalliṣinā Yasū' al-Masīḥ 18/04/2014, https://www.facebook.com/pg/lattakiaorthodox/photos/?tab=album\&album_id=496471627120900. 


\section{OBYCZAJE ŚWIĄTECZNE - PASCHA}

Noc Paschalna w rycie bizantyjskim to cykl kilku następujących bezpośrednio po sobie nabożeństw: Połunoszcznica Paschalna, która ma jeszcze wielkosobotni charakter; Zautrenia Paschalna, czyli zapalenie świec przez wiernych od kapłana, otwarcie carskich wrót, procesja trzykrotnie okrążająca świątynię, modlitwy paschalne przed nią oraz ceremonia otwarcia drzwi cerkwi; Jutrznia Paschalna; Paschalne Godziny Kanoniczne; Boska Liturgia. U Arabów zwłaszcza Zautrenia Paschalna, nazywana Al-Hağma ${ }^{61}$ - czyli „atak”, „najazd”, „szturm” - jest bardzo charakterystyczna przez obrzęd otwarcia drzwi, będący tytułowym atakiem. Część tradycji zarzuciła tego obrzędu - kapłan po prostu po dopełnieniu śpiewów przed świątynią otwiera je krzyżem lub paschalnym świecznikiem. Jednak Arabowie zachowali tę ceremonię w starszej wersji, który jest analogiczny do tego z konsekracji cerkwi. Następuje tu dialog pomiędzy kapłanem a wybranym wiernym, który został w środku świątyni na czas procesji, będący wersami psalmu 23:

Kapłan: Podnieście wasze bramy, władcy; niech podniosa się odwieczne bramy, i niech wejdzie Król chwały!

Osoba wewnątrz: Któż jest tym Królem chwały?

Kapłan: Pan mocny i potężny, Pan mocny $w$ wojnie. Podnieście wasze bramy, władcy; niech podniosa się odwieczne bramy, i niech wejdzie Król chwaly!

Osoba wewnątrz: Któż jest tym Królem chwaty?

Kapłan: Pan mocny i potężny, Pan mocny $w$ wojnie. Podnieście wasze bramy, władcy; niech podniosa się odwieczne bramy, i niech wejdzie Król chwały!

${ }^{61}$ Mādā ta'nī hağma 'ìd Al-Fiṣh ? ?, https://www.lbcgroup.tv/news/d/easter/ 209696/\%D9\%85\%D8\%A7\%D8\%B0\%D8\%A7-\%D8\%AA\%D8\%B9\%D9\%86\%D9\%8A- \%D9\% 87\%D8\%AC\%D9\%85\%D8\%A9-\%D8\%B9\%D9\%8A\%D8\%AF-\%D8\%A7\%D9\%84\%D9\%81\%D8\%B5\%D8\%AD/ar [dostęp: 12.09.18]. 
Osoba wewnątrz: Któż jest tym Królem chwały?

Kapłan: Pan Zastępów - On jest Królem chwały!62

Duchowny za każdym razem trzykrotnie uderza dłonią drzwi cerkwi; jeśli jest to biskup, czyni to swoim małym ewangeliarzem ${ }^{63}$. Po tym duchowny pcha drzwi. Kapłani, asysta liturgiczna z pochodniami, chorągwiami i ikonami oraz wszyscy pozostali wierni wchodzą do świątyni przy śpiewie Kanonu Paschy lub troparionem Paschy, a potem jej kanonem. To wejście nierzadko jest bardzo entuzjastycznie przyjmowane przez wiernych - towarzyszą mu okrzyki i gwizdy ${ }^{64}$. Ta ceremonia symbolizuje odwalenie kamienia od grobu Chrystusa, a co za tym idzie - skruszenie okowów śmierci. Po wejściu do cerkwi bywają trącane żyrandole na znak świątecznej radości ${ }^{65}$.

Na koniec Liturgii święcone są pokarmy: zazwyczaj same jajka, najczęściej pomalowane (niekoniecznie tylko na czerwono, jak jest to w Serbii czy Grecji) ${ }^{66}$; mogą też jednak pojawić się prosfory (chleb z krzyżem lub pieczęcią Chrystusa), słodycze czy ser - różnice występują nawet $\mathrm{w}$ ramach jednej diecezji ${ }^{67}$. Typikon (księga regulacji liturgicznych) Patriarchatu Antiocheńskiego na rok 2018 przewiduje święcenie jajek i sera ${ }^{68}$, ale np. euchologion (księga przedstawiająca przebieg obrzędów i modlitw na specjalne okoliczności) arabski zawiera modlitwę poświę-

62 Hidmat Ahad al-Fiṣh al- 'Aḍim al-Muqaddas, Dibbīn 2010, s. 20-21.

${ }^{63}$ Zob. np. Muqātì min Al-Hağma wa-Quddās al-Fiṣh fō Tarṭūs, https://www. youtube.com/watch?v=wYOh6s9aWXY [dostęp: 12.09.18].

${ }^{64}$ Zob. np. Hajme Tripoli El Mina 2014 By Micha Hajjar, https://www.youtube. com/watch?v=ifhhvcKNQhc [dostęp: 12.09.18].

${ }^{65}$ Zob. np. Hidmat al-Hağma. Kanīsat Mār Ğirğis, https://www.youtube.com/ watch?v=rILg4hdgeRs [dostęp: 12.09.18].

66 Zob. np. Ahad al-Fiṣh al-Mağìd 2014, Kanīsat Mār Andrāwus, https://www. facebook.com/pg/lattakiaorthodox/photos/?tab=album\&album_id=497086720392724 [dostęp: 12.09.18].

67 Zob. np. Aḥad al-Fiṣh al-Mağìd 2014, Kanīsat MārYūhannā, https://www. facebook.com/pg/lattakiaorthodox/photos/?tab=album\&album_id=497234653711264 [dostęp: 12.09.18].

${ }^{68}$ Dalìl Al-Kursī al-Anțākī 2018, https://www.antiochpatriarchate.org/images/ pages/tipicon2018-01-15-05-46-20.pdf [dostęp: 12.09.18], s. 81. 
cenia pokarmów mięsnych w Niedzielę Paschy ${ }^{69}$. Po rozesłaniu każdy - jak zawsze na Liturgii - podchodzi do kapłana, by ucałować trzymany przez niego krzyż, i wówczas wierny dostaje poświęcone jajko lub zestaw paschalnych pokarmów. Dla porównania, w polskiej praktyce również wszyscy dostają pomalowane na czerwono lub zielono pobłogosławione jajka, jednak święcenie pokarmów - różnych, włożonych do koszyka odbywa się w Wielką Sobotę, na koniec Liturgii św. Bazylego lub jeszcze później. W każdym razie, tymi błogosławionymi pokarmami w każdej prawosławnej tradycji zrywa się post: 2-dniowy od wszelkiego jedzenia, 48-dniowy od nabiału, a 55-dniowy od mięsa. W tradycji arabskiej dopiero po poświęceniu pokarmów - a nie na koniec jutrzni, jak jest to gdzie indziej - czyta się wielkanocną homilię św. Jana Chryzostoma ${ }^{70}$.

Wieczernia Paschalna celebrowana jest wcześniej, niż zwykła wieczernia, co wiąże się z tym, że Liturgia paschalna sprawowana jest nad ranem. Różnie się ją określa - w tradycji arabskiej jej nazwa to Salāt

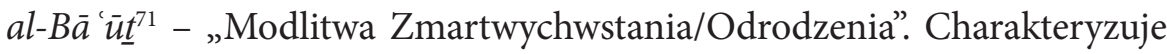
się ona dwa elementami. Pierwszy z nich to Ewangelia (J 20, 19-25) czytana $\mathrm{w}$ różnych językach ${ }^{72}$ na znak uniwersalnego tryumfu wiary i przekazania Dobrej Nowiny każdemu człowiekowi. Jest to właściwie jedyna sytuacja, kiedy Ewangelię może czytać osoba świecka ${ }^{73}$, co często tego dnia ma miejsce (każdy czyta w swoim języku), nie tylko zresztą w tradycji arabskiej. Drugi to procesja - nie tak refleksyjna, jak w Paschalną Noc, a bardziej huczna. W tradycji arabskiej towarzyszą ją często inscenizacje wielkotygodniowych wydarzeń oraz innych biblijnych, różne instalacje na platformach czy samochodach ${ }^{74}$, śpiewy i okrzyki - są one różne, gdyż typikon mówi tylko, iż mają być one paschalne ${ }^{75}$. Towarzyszą

${ }^{69}$ Kitāb al-Afh̆ù ūì̄i al-Kabìr, s. 643.

70 Dalìl Al-Kursī al-Anțākī 2018, s. 81.

${ }^{71}$ At-Ta ziya al-Haqiqiyya fì ăș-Salawāt al-Ilahiyya, s. 727.

72 Dalìl Al-Kursī al-Anțākī 2018, s. 82.

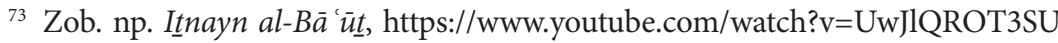
[dostęp: 13.09.18].

${ }^{74}$ Zob. np. Dawrat Itnayn al-Bā'üt fī Kafrbū 2009, https://www.youtube.com/ watch?v=eEoSOeazRTQ [dostęp: 13.09.18]

75 Dalìl Al-Kursī al-Anțākī 2018, s. 82. 
im niekiedy tańce $\mathrm{z}$ ikonami i oklaski ${ }^{76}$ oraz pokazy szabel ${ }^{77}$. U Arabów ta sama Ewangelia oraz procesja również w identycznej formie są także bezpośrednio po Liturgii Paschalnego Poniedziałku ${ }^{78}$ - to nietypowe dla innych tradycji, gdzie w Tygodniu Paschalnym oraz niedziele Okresu Paschalnego z tych dwóch elementów są tylko procesje, jednak bez wyżej wymienionych cech charakterystycznych.

\section{OBYCZAJE ŚWIĄTECZNE - ŚWIĘTO PODWYŻSZENIA KRZYŻA}

Drugim z grona 12 największych świąt cerkiewnych (nie wlicza się w nie Święta Świąt - Paschę) w roku liturgicznym, rozpoczynającym się 1 września, jest Podwyższenie Krzyża, obchodzone 14 września. W całym rycie bizantyjskim jest to dzień ścisłego postu - albo w ogóle nie spożywa się posiłków, albo takie nie zawierające mięsa, nabiału, ryby i oleju ${ }^{79}$. W tradycji arabskiej po wielkiej wieczerni w wigilię święta odbywa się szczególny obrzęd - rozpalenie i poświęcenie ogniska przed cerkwią przy śpiewie troparionu Świętego Krzyża. Rytuał ten ma nawiązywać do podania, że święta Helena, gdy znalazła Krzyż Zbawiciela, chcąc jak najszybciej poinformować o tym swego syna - cesarza Konstantyna - poleciła rozpalić jak najwięcej ognisk na terenie imperium ${ }^{80}$. Ogniska te bywają też rozpalane na centralnych placach i wierzchołkach gór ${ }^{81}$. W spółcześnie mogą im towarzyszyć inne atrakcje związane ze światłem, jak np. pokazy

${ }^{76}$ Zob. np. Al-Bā' 'ūt fì Mharda: kanīsa Yuwākìm wa-Hanna 2012, https://www. youtube.com/watch?v=Z0wZDTj5gzE [dostęp: 13.09.18].

77 Zob. np. Dawrat Al-Bā' 'üt fì baladat Al-Mašrafa 2018, https://www.youtube. com/watch?v=pVCvoF5HnV4 [dostęp: 13.09.18].

78 Dalìl Al-Kursī al-Anțākī 2018, s. 82.

79 Tamże, s. 153.

80 'İd Raf' aṣ-Ṣalīb al-Karīm al-Muhayyī, https://www.antiochpatriarchate.org/ar/page/\%D 8\%B9\%D9\% 8A\%D $\%$ AF-\%D 8\%B1\%D9\%81\%D8\% B 9 - \% D 8 \% A 7 \% D $9 \% 84$ \% D 8 \% B 5 \% D 9\% 84 \% D $9 \% 8$ A \% D 8 \% A 8 - \% D 8 \% A 7\%D9\%84\%D9\%83\%D8\%B1\%D9\%8A\%D9\%85-\%D8\%A7\%D9\%84\%D9\%85\%D8\%AD\%D9\%8A-\%D9\%8A/1490/ [dostęp: 15.09.18]

81 Tamże. 
laserowe czy fajerwerków ${ }^{82}$. Zwyczaj palenia ognisk na to święto istnieje również $\mathrm{w}$ tradycji etiopskiej ${ }^{83}$.

Inną tradycją - nieobecną w Polsce, ale praktykowaną np. wśród Greków - jest rozdanie wiernym po Boskiej Liturgii w dniu święta kwiatów i listków, którymi przyozdobiono nieduży krzyż wyniesiony na środek świątyni na koniec jutrzni ${ }^{84}$. Celem tego zwyczaju jest przypomnienie, iż krzyż chrześcijanina $\mathrm{w}$ pewnym momencie zakwitnie radością, życiem, chwała i zmartwychwstaniem ${ }^{85}$.

\section{OBYCZAJE ŚWIĄTECZNE - ŚWIĘTYCH JANA DAMASCEŃSKIEGO I BARBARY}

Czwartego grudnia Cerkiew prawosławna obchodzi pamięć dwojga świętych związanych z Lewantem: wielkiej męczennicy Barbary oraz Jana Damasceńskiego. Choć jest to połowa Postu Bożonarodzeniowego, który $\mathrm{w}$ rycie bizantyjskim rozpoczyna się 15 listopada, to dzień ten w tradycji arabskiej ma zdecydowanie charakter świąteczny, a nie ascetyczny. Właściwie przypomnieniem tego drugiego jest tylko specjalna potrawa przygotowywana na ten dzień: al-qamh al-maslūq, czyli "gotowana pszenica”, u Słowian znana jako „koliwo”, aczkolwiek Arabowie też czasem stosują to słowo jako zapożyczenie: al-kūliffāa $\bar{c}^{86}$. Potrawa ta, oprócz tytułowej pszenicy, zawiera również miód oraz różne zmielone, postne ( $\mathrm{tj}$. bez produktów pochodzenia zwierzęcego, oliwy i oleju) składniki, np. orzechy. Poszczególne regiony a nawet rodziny stosują własne receptury, które różnią się proporcjami i użytymi składnikami. Zazwyczaj koliwo przybiera ozdobną formę, np. z migdałów lub orzechów ułożony jest krzyż. W rycie bizan-

8213 Aylūl 2018 șalāt ihtifāl 'ìd raf' aṣ-Ṣalīb al-Karìm al-Muhayyì, https:// www.facebook.com/pg/HOLY.CROSS.CHURCH.SY/photos/?tab=album\&album _ $\mathrm{id}=2148095618598778$ [dostęp: 15.09.18].

${ }^{83}$ Zob. więcej Commemoration feast of the finding of the True Holy Cross of Christ, https://ich.unesco.org/en/RL/commemoration-feast-of-the-finding-of-the-true-holy-crossof-christ-00858 [dostęp: 15.09.18].

84 'İd Raf' aṣ-Ṣalīb al-Karīm al-Muhayyī.

85 Tamże.

${ }^{86}$ R. Haddād, Limādā nasluq al-qamh fì 'ìd al-qiddīsa Barbāra?, http://noursatjordan.com/news-details.php?id=61629 [dostęp: 16.09.18]. 
tyjskim potrawa ta jest przygotowywana przede wszystkim w pierwszą sobotę Wielkiego Postu oraz na pogrzeby i inne nabożeństwa za zmarłych. Arabowie zatem nawiązują tu do tradycji drugiego 40-dniowego postu (obok tego Wielkiego), jakim jest Adwent, a także do słów Ewangelii odnośnie męczeństwa patronki dnia: „Jeżeli ziarno pszenicy wpadłszy w ziemię nie obumrze, zostanie tylko samo, ale jeżeli obumrze, przynosi plon obfity." (J 12, 24). Istnieje też tradycja, iż św. Barbara uciekając przed swym despotycznym ojcem, skryła się w polu pszenicy ${ }^{87}$. Koliwo jest błogosławione na koniec Boskiej Liturgii tego dnia, i rozdawane wszystkim przybyłym wiernym ${ }^{88}$.

Wymiar świąteczny to przede wszystkim zwyczaj procesji przechodzących przez osiedle lub miejscowość, kiedy dzieci i młodzież są przebrane za różne postaci, np. z bajek - w takich strojach tego dnia przychodzą również do cerkwi - a wszyscy śpiewają ludowe piosenki związane ze św. Barbarą, przy tym tańcząc. To również dzień odwiedzin rodziny i znajomych oraz zasiadania do wspólnych posiłków ${ }^{89}$. Obchody te na terenie Syrii, Libanu i Palestyny łączą chrześcijan różnych wyznań i obrządków, a nawet również muzułmanów ${ }^{90}$.

\section{PODSUMOWANIE}

Dokonując przeglądu wybranych w tym opracowaniu zwyczajów liturgicznych i ludowych prawosławnych Arabów, można dojść do dwóch wniosków.

Po pierwsze, kultura arabska, choć niewątpliwie na przestrzeni wieków zdominowana przez islam, jest również kształtowana przez wyznawców Chrystusa, zwłaszcza tych wyznania prawosławnego. Pewną koegzystencję islamu i prawosławia w ramach kultury arabskiej można zauważyć choćby w niektórych wspólnych stosowanych zwrotach, jak np. przytoczone w okoliczności śmierci, czy obchody 4 grudnia. Również

87 Tamże.

88 Tamże.

${ }^{89} \mathrm{~S}$. Kāmal, 'İd al-qiddīsa Al-Barbāra.. țaqs sūrī ša 'bī yağma' kull ad-diyānāt, http://alkhabar-sy.com/?p=9222 [dostęp: 16.09.18].

90 Tamże. 
to, iż niektóre zwyczaje - np. ogniska na święto Podwyższenia Krzyża - i nazwy są stosowane przez chrześcijan różnych wyznań, wskazuje na swoistą różnorodność kultury arabskiej, w ramach jednak pewnej całości.

Po drugie, bez wątpienia można mówić, że takie pojęcie jak „arabskie prawosławie" istnieje i są do tego podstawy, które wynikają z tego, że prawosławni Arabowie 1) wykształtowali własną terminologię liturgiczną, w tym potoczne określenia związane z liturgiką; 2) ich zwyczaje, choć bardzo bliskie greckim, nie są do końca z nimi tożsame, i czerpią również $\mathrm{z}$ innych tradycji, istnieją też rodzime - zatem sformułowanie Ar-Rūm alUrt $\underline{\underline{u}} \underline{\mathrm{d} u k s}$ odnosi się do rytu bizantyjskiego jako pewnego szkieletu, a nie dokładnej kopii zwyczajów greckich, podobnie jak to funkcjonuje u np. Rumunów czy różnych Słowian, ponadto w kontekście bliskowschodnim to określenie wiąże się też z odróżnieniem od prawosławnych dochalcedońskich, czyli innych rytów (niekoniecznie jednak innej teologii ${ }^{91}$ ); 3) pewne cechy charakterystyczne zarówno na polu liturgicznym, jak i ludowym, nawet mimo zamieszkania w innym kraju i używania angielskiego lub hiszpańskiego jako pierwszego języka są zachowywane, a wręcz przekazywane innym etnosom, co jest zauważalne choćby w przetłumaczeniu i śpiewaniu - mimo że to narusza pewną konstrukcję liturgiczną według innych tradycji - pieśni Raduj się Betanio.

\section{BIBLIOGRAFIA}

13 Aylūl 2018 șalāt iḥtifāl 'ìd raf' aș-Ṣalīb al-Karìm al-Muhayyī, https://www.facebook.com/pg/HOLY.CROSS.CHURCH.SY/photos/?tab=album\&album_ id $=2148095618598778$ [dostęp: 15.09.2018].

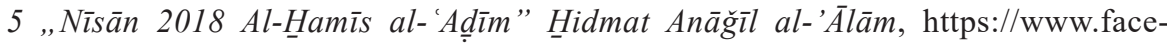
book.com/pg/HOLY.CROSS.CHURCH.SY/photos/?tab=album\&album_ id=1876555369086139 [dostęp: 11.09.2018].

Adyoutube.com/watch?v=AntGTCJ28UA [dostęp: 13.07.2018].

Ahad al-Fiṣh al-Mağìd 2014, Kanīsat Mār Andrāwus, https://www.facebook.com/ pg/lattakiaorthodox/photos/?tab=album\&album_id=497086720392724 [dostęp: 12.09.2018].

${ }^{91}$ Zob. poszczególne dokumenty i relacje z niektórych spotkań na stronie Orthodox Unity (Orthodox Joint Commission), https://orthodoxjointcommission.wordpress. com [dostęp: 29.09.18]. 
Aḥad al-Fiṣh al-Mağ̄id 2014, Kanīsat MārYūḥannāa, https://www.facebook.com/pg/ lattakiaorthodox/photos/?tab=album\&album_id=497234653711264 [dostęp: 12.09.2018].

Al-Bā' üu fì Mharda: kanīsa Yuwākìm wa-Hanna 2012, https://www.youtube.com/watch?v=Z0wZDTj5gzE [dostęp: 13.09.2018].

Al-Fuḥayṣ.. tārīh hăfil wa-mutağaddirir, https://www.ammonnews.net/article/140275 [dostęp: 08.08.2018].

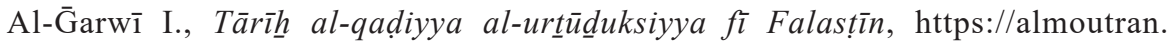
com/2011/04/1247 [dostęp: 04.07.2018].

Al-Mutallat Ar-Raḥmāt al-mațrān Ğrī̄̄üriyūs Ğabāra, https://www.orthodoxlegacy. org/?p=196 [dostęp: 06.09.2018].

Al-Quddās al-Ilahī wa-ma 'ānīh, https://almoutran.com/2011/04/1216 [dostęp: 06.08.2018]. Antiochian Women of the East (AWE), http://ww1.antiochian.org/awe [dostęp: 26.07.2018]. Aš-Ša 'ānīn fì ad-dār al-bațriyarkiyya fì Dimašq min al-kanīsa Al-Maryamiyya, https:// www.facebook.com/pg/Antiochpatriarchate.org/photos/?tab=album\&album _ $\mathrm{id}=914698888633825$ [dostęp: 06.09.2018].

At-Ta ziya al-Haqīqiyya fì ăș-Salawāt al-Ilahiyya, New York 1940.

Chadi Karam Byzantine chanting on Pentecost, https://www.youtube.com/watch?v=5YdOKJjn2jQ [dostęp: 01.09.2018].

Commemoration feast of the finding of the True Holy Cross of Christ, https://ich. unesco.org/en/RL/commemoration-feast-of-the-finding-of-the-true-holy-crossof-christ-00858 [dostęp: 15.09.2018].

Dalīl Al-Kursī al-Anțākī 2018, https://www.antiochpatriarchate.org/images/pages/tipicon2018-01-15-05-46-20.pdf [dostęp: 12.09.2018].

Dawrat Al-Bā 'üt fì baladat Al-Mašrafa 2018, https://www.youtube.com/watch?v=pVCvoF5HnV4 [dostęp: 13.09.2018].

Dawrat Itnayn al-Bā' ūt fì Kafrbū 2009, https://www.youtube.com/watch?v=eEoSOeazRTQ [dostęp: 13.09.2018].

Faith under occupation. The Plight of Indigenous Christians in the Holy Land, red. M. Nseir, M. Quintero, P. Nunu, N. Muaddi, Y. Daher, 2012.

Haddād R., Limā news-details.php?id=61629 [dostęp: 16.09.2018].

Hajme Tripoli El Mina 2014 By Micha Hajjar, https://www.youtube.com/watch?v=ifhhvcKNQhc [dostęp: 12.09.2018].

Hamīs al-Asrār al-Muqaddas- Usbū' al-'Ālām - ḡasl al-arğul, http://greekorthodox-beitsahour.blogspot.com/2014/04/blog-post_17.html [dostęp: 10.09.2018].

Hidmat Ahad al-Fiṣh al-'Aḍīm al-Muqaddas, Dibbīn 2010.

Hidmat al-Hağma.. Kanīsat Mār Ǧirğis, https://www.youtube.com/watch?v=rILg4hdgeRs [dostęp: 12.09.2018].

Hidmat ğannāz Rabbinā wa-Muhallișinā Yasū' al-Masịh 18/04/2014, https://www.facebook.com/pg/lattakiaorthodox/photos/?tab=album\&album_id=496471627120900 [dostęp: 12.09.2018]. 
http://www.antiochian-orthodox.co.uk/sayidna/message-sayedna-silouan-october-2017/ [dostęp: 02.08.2018].

https://orthodoxjointcommission.wordpress.com [dostęp: 29.09.2018].

https://www.facebook.com/fuheis/photos/a.661283083882301/1146068218737116/ [dostęp: 30.08.2018].

https://www.facebook.com/fuheis/photos/a.661283083882301/2115367438473851/[dostęp: 30.08.2018].

https://www.facebook.com/GreekOrthodoxArchdiocesesOfZahle/photos/a$.478407512260814 .1073741829 .352813064820260 / 1316678991766991 /$ type$=3 \&$ theater [dostęp: 11.09.2018].

h t t p s : / / w w w facebook. com/Lat takiaorthodoxdeat h/photos/a.597079183765673/1172065269600392 [dostęp: 02.09.2018].

https://www.facebook.com/pg/\%D 9\%83\%D 9\%86\%D9\%8 A \% D 8\%B3\% D8\%A9-\%D8\%A7\%D9\%84\%D9\%82\%D8\%AF\%D9\%8A\%D8\%B3-\%D8\%AC\%D8\%A7\%D9\%88\%D8\%B1\%D8\%AC\%D9\%8A\%D9\%88\%D8\%B3-\%D8\%A7\%D9\%84\%D8\%B3\%D9\%84\%D8\%B7-Saint-George-Church-Salt-387124751342927/photos/?tab=albums [dostęp: 08.08.2018].

https://www.facebook.com/pg/Lattakiaorthodoxdeath/about/?ref=page_internal [dostęp: 02.09.2018].

https://www.stlukeorthodox.net/administration.html [dostęp: 02.08.2018].

Hudụr Ğ., Ahad aš-Ša 'ānīn, „Ra iyyatî”, 2009, nr 15.

Huḍr Ğ., Al-Bațriyark, „Ra iyyat̄̄”, 2012, nr 52.

'İd Raf' aș-Ṣalīb al-Karīm al-Muhayyi, https://www.antiochpatriarchate.org/ ar/page/\%D8\%B9\%D9\%8A\%D8\%AF-\%D8\%B1\%D9\%81\%D8\%B9- \% D $8 \%$ A $7 \%$ D $9 \% 84 \%$ D $8 \%$ B $5 \%$ D 9\% $84 \%$ D $9 \% 8$ A \% D $8 \%$ A 8 - \%D8\%A7\%D9\%84\%D9\%83\%D8\%B1\%D9\%8A\%D9\%85-\%D8\%A7\%D9\%84\%D9\%85\%D8\%AD\%D9\%8A-\%D9\%8A/1490/ [dostęp: 15.09.2018].

Itnayn al-Bā' ūt fì dayr Mār Ilyās ar-R̄̄h, https://www.facebook.com/pg/tartous.orthodox/ photos/?tab=album\&album_id=1722114207848790 [dostęp: 21.07.2018].

Intnayn al-Bā 'üt, https://www.youtube.com/watch?v=UwJlQROT3SU [dostęp: 13.09.2018]. Kāmal S., İd al-qiddīsa Al-Barbāra.. țaqs sūrī ša 'b̄̄ yağma' kull ad-diyānāt, http:// alkhabar-sy.com/?p=9222 [dostęp: 16.09.2018].

Kitāb al-Afhūūūgī al-Kabīr, Beirut 1955.

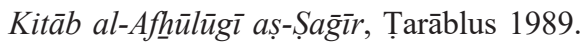

Kościelniak K., Grecy i Arabowie: historia Kościoła melkickiego (katolickiego) na ziemiach zdobytych przez muzutmanów: (634-1516), Kraków 2004.

Koski D., Roum Orthodox Traditions of Beit Jala, Palestine. A paper for the occasion of the Conference on Palestinian Tourism and Antiquities Between Current Challenges and Prospects, held December 14th, 2013.

Lubnān yuwaddi ‘̌ahīdan ğarīmat Isțanbūl al-irhābiyya Ilyās Wardīn̄̄ wa-haykal muslim wasat hidād wațan̄, https://www.youtube.com/watch?v=-BSRUnQBS4A [dostęp: 06.09.2018]. 
Mādā ta'n̄ hağma 'ìd Al-Fiṣh? ?, https://www.lbcgroup.tv/news/d/easter/209696/ \%D 9\%85\%D 8\%A 7\%D 8\%B 0\%D 8\%A 7-\%D 8\%AA\%D8\%B9\%D9\% $86 \%$ D 9\%8 A - \% D 9\%87\%D 8\%AC\%D 9\% 85\%D 8\%A 9- \% D 8\%B $9 \%$ D9\%8A\%D8\%AF-\%D8\%A7\%D9\%84\%D9\%81\%D8\%B5\%D8\%AD/ar [dostęp: 02.08.2018].

Mazmūr Al-Mīlād.. ğawqat kanīsat Mār Ilyās, https:/www.facebook.com/kfarbou.site/ videos/1121124667911630/ [dostęp: 08.08.2018].

Muqātic 'min Al-Hağma wa-Quddās al-Fiṣh fị Tarțūs, https://www.youtube.com/watch?v=wYOh6s9aWXY [dostęp: 09.09.2018].

Nașrallāh J., Manșūr Ibn Sarğūn at-Tàglibī Al-Ma'arūf Bi-ăl-Qiddīs Yūhannā ad-Dimašqū Aw Al-Fatah Al-Islāmī As-Sahl li-ăl-Madīna Dimašq wa Asbābuh, 1950.

Quddās Hamīs al-Asrār Dawrat al-Qarābīn, https://www.youtube.com/watch?v=MOU6zwyODfk [dostęp: 06.08.2018].

Quddās Hamīs al-Asrār dawrat Al-Qarābīn, https://www.youtube.com/watch?v=MOU6zwyODfk [dostęp: 10.09.2018].

Quddās 'ìd Al-Mīlād al-Mağìd min al-katidrā'iyya al-Maryamiyya li-r-rūm al-urțuduks bi-Dimašq, https://www.youtube.com/watch?v=HhWkqBaOHqk [dostęp: 12.07.2018].

Rejoice, $O$ Bethany, http://ww1.antiochian.org/sites/default/files/rejoice_o_bethany.pdf [dostęp: 06.09.2018].

Shahid I., Byzantium and the Arabs in the fifth century, Washington D.C. 1989.

Shahid I., Byzantium and the Arabs in the fourth century, Washington D.C. 1984.

Talātiyyat 'ìd al-Fiṣh, https://antiochpatriarchate.org/ar/page/\%D8\%AB\%D9\%84\%D8\%A7\%D8\%AB\%D9\%8A-\%D8\%A9-\%D8\%B9\%D9\%8A\%D8\%AF-\%D8\%A7\%D9 \%84\%D9\%81\%D8\%B5\%D8\%AD/1413/ [dostęp: 11.09.2018].

Tanzīl Al-Mașlūb, https://www.youtube.com/watch?v=ws8GHvSr0-I [dostęp: 11.09.2018].

The Orthodox Church in the Arab World 700-1700. An Anthology of Sources, red. S. Noble i A. Treiger, 2014.

Triyūdūn, Ṭarābulus 1996.

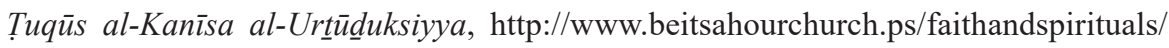
ourfaith/ritual [dostęp: 09.08.2018].

Zayyāḥ Ǎ̌s-Ša'nī fì kanīsa As-Sayyida bi-Ṭarțūs 2014, https://www.youtube.com/wat$\mathrm{ch}$ ?v=qd9TFfd-Qoo [dostęp: 06.08.2018]. 